\title{
Interference of Plectranthus amboinicus (Lour.) Spreng essential oil on the anti-Candida activity of some clinically used antifungals
}

\author{
Rinalda de Araújo G. de Oliveira ${ }^{1}$ Edeltrudes de O. Lima ${ }^{2 *}$, Evandro L. de Souza ${ }^{3}$, Wellington \\ L. Vieira ${ }^{2}$, Kristerson R. L. Freire ${ }^{2}$, Vinícius N. Trajano², Igara O. Lima ${ }^{2}$, \\ Raimundo N. Silva-Filho ${ }^{1}$
}

${ }^{1}$ Laboratório de Tecnologia Farmacêutica, Universidade Federal da Paraíba, Caixa Postal 5009, 58051-970, João Pessoa, PB, Brasil,

${ }^{2}$ Laboratório de Micologia, Departamento de Ciências Farmacêuticas, Universidade Federal da Paraíba, 58051-970, João Pessoa, PB, Brasil,

${ }^{3}$ Departamento de Nutrição, Centro de Ciências da Saúde, Universidade Federal da Paraíba, 58051-970, João Pessoa, PB, Brasil

\begin{abstract}
RESUMO: “Interferência do óleo essencial de Plectranthus amboinicus (Lour.) Spreng sobre a atividade anti-Candida de alguns antifúngicos utilizados clinicamente”. As plantas com propriedades medicinais têm sido utilizadas por um longo tempo no cuidado tradicional de saúde, de modo que algumas vezes seu uso ocorre concomitantemente ao uso de drogas industrializadas. O objetivo deste estudo foi avaliar a interferência do óleo essencial de Plectranthus amboinicus sobre atividade anti-Candida de alguns antifúngicos utilizados clinicamente através do método de difusão em meio sólido. Os antifúngicos ensaiados foram anfotericina B $(100 \mu \mathrm{g} / \mathrm{mL})$, cetoconazol $(50 \mu \mathrm{g} / \mathrm{mL})$ e itraconazol $(50 \mu \mathrm{g} / \mathrm{mL})$. C. albicans, C. tropicalis, C. guilliermondii, C. krusei e C. stellatoidea foram utilizadas como microrganismos testes. O óleo essencial de P. amboinicus mostrou um valor de CIM de $40 \mu \mathrm{L} / \mathrm{mL}$ para a maioria das cepas de leveduras ensaiadas. O óleo essencial quando ensaiado em sua CIM mostrou alguma interferência sobre a efetividade antiCandida dos antifúngicos testados, sendo notada a formação de zonas de inibição do crescimento fúngico com diferentes diâmetros quando os antifúngicos foram testados isolados e em combinação com o óleo essencial. O óleo essencial de $P$. amboinicus mostrou destacável interferência sobre a atividade antifúngica de itraconazol, sendo observado um efeito sinérgico sobre $C$. albicans, $C$. tropicalis, C. krusei e C. stellatoidea. Ademais, o óleo essencial interferiu na atividade antifúngica de cetoconazol sobre C. albicans, C. guilliermondii e C. stellatoidea causando, respectivamente, efeito antagônico e sinérgico. De outra forma, foi observada uma pequena interferência do óleo essencial sobre o efeito antifúngico de anfotericina B. Estes dados mostram que o uso combinado de plantas medicinais e/ou seus produtos derivados com drogas industrializadas, particularmente, antimicrobianos podem interferir sobre os efeitos terapêuticos esperados.
\end{abstract}

Unitermos: Plectranthus amboinicus, óleo essencial, antifúngicos.

\begin{abstract}
Plants with medicinal properties have been applied for a long in the traditional health care, so that sometimes their use takes place concomitantly to the use of industrialized drugs. The aim of this study was to evaluate the interference of Plectranthus amboinicus essential oil on the anti-Candida activity of some clinically used antifungals by the solid medium diffusion procedure. Assayed antifungals were amphotericin B $(100 \mu \mathrm{g} / \mathrm{mL})$, ketoconazole $(50 \mu \mathrm{g} / \mathrm{mL})$ and itraconazole (50 $\mu \mathrm{g} / \mathrm{mL})$. C. albicans, C. tropicalis, C. guilliermondii, C. krusei and C. stellatoidea were used as test microorganisms. $P$. amboinicus essential oil showed MIC value for most assayed yeast strains. The essential oil when assayed in its MIC value showed some interference on the antiCandida effectiveness of the assayed antifungals. It was noted yeast growth inhibition zones with different diameters when the antifungals were tested alone and combined with the essential oil. $P$. amboinicus essential oil showed prominent interference on the anti-yeast activity of itraconazole providing a synergic effect on C. albicans, C. tropicalis, C. krusei and C. stellatoidea. Also, the essential oil interfered on the anti-yeast activity of ketoconazole when interacting with C. albicans, C. guilliermondii and C. stellatoidea providing, respectively, an antagonic and synergic effect. On the other hand, it was found a small interference on the anti-yeast effect of amphotericin $\mathrm{B}$. These data showed that combined use of medicinal plants and/or derivatives with industrialized drugs, particularly antimicrobials, could interfere on their expected therapeutic effects.
\end{abstract}

Keywords: Plectranthus amboinicus, essential oil, antifungals. 


\section{INTRODUCTION}

Candida species are reported as the yeasts most frequently involved in mycotic infections etiology (Wilhelmus, 2005). Candidiasis is the most common mycotic infection being C. albicans its most important causing agent, although C. guilliermondii, C. krusei, C. parapsilosis, C. stellatoidea and C. tropicallis have been also reported as potential etiological agents (Schwartz, 2004; Duarte et al., 2005; Lima et al., 2006a,b).

Plants with medicinal properties have been focus of scientific studies all over the world in order to discover new and effective antimicrobial compounds (Radhrakrishanan-Sridhar et al., 2003; Burt, 2004; Lima et al., 2006c; Packer \& Luz, 2007). World Health Organization (WHO) estimates that about 65 to $80 \%$ of the world population trust on traditional health care practices which are mainly based on the use of medicinal plants and derivatives. Still, the WHO has recommended the planning of studies for evaluating the safety and effectiveness of phytotherapeutic products in order to promote their correct use by population (Calixto, 2000; Aguiar, 2004).

The concomitant use of medicinal plants and derivatives with industrialized drugs has been observed in some ethnopharmacological studies (Dorigoni, 2001; Veiga Júnior et al., 2005). This practice has been found as consequence of self-medication or even of health professional advising and includes the use of decocts, infusions, teas, extracts, macerates, plasters, essential oils and powders from medicinal plants (Sucar, 2003; Oliveira et al., 2006). Drugs association means the possibility of interactions which could result in enhanced therapeutic answer, antagonic effect to the used drug or decreased side effects (Brinker, 1998; Seidil, 2000).

Plectranthus amboinicus (Lour.) Spreng, Lamiaceae, is a perennial, aromatic, juicy and erect plant with length varying from $5 \mathrm{~cm}$ to $1 \mathrm{~m}$. The plant is found in all Tropical America since the Antilles up to Brazil South (Castillo; Gonzáles, 1999). P. amboinicus is widely used in the Brazilian folk medicine to treat skin diseases and its leaves are topically used for the treatment of furuncles and superficial mycosis. Still, it is popularly used for treating flue, constipation, cephalea, cough, hoarseness, fever and digestive diseases (Lorenzi; Matos, 2002; Sellar, 2002; Tôrres et al., 2005; Morais et al., 2005).

Regarding the lack of scientific studies about the interference of medicinal plants and derivatives on the effectiveness of industrialized drugs, particularly antimicrobials, this study aimed at evaluating the interference of $P$. amboinicus essential oil on the antiCandida activity of some clinically used antifungals.

\section{MATERIAL AND METHODS}

\section{Plant material}

Plectranthus amboinicus (Lour.) Spreng leaves were collected from the plant collection of the Laboratório de Tecnologia Farmacêutica, Universidade Federal da Paraíba (João Pessoa, Brazil) in May, 2004. Whole plant was sent to Herbário IPA - Dárdamo de Andrade Lima, Empresa Pernambucana de Pesquisa Agropecuária (Recife, Brazil) for its botanic identification. A voucher specimen was deposited at the same herbarium under a number of 65001 IPA.

$P$. amboinicus essential oil was obtained by hydrodistillation procedure using the Clevenger apparatus. Essential oil solutions at concentrations ranging from 320 to $2.5 \mu \mathrm{L} / \mathrm{mL}$ prepared according to Souza et al. (2005) were used in the antimicrobial assays.

\section{Microbial strains}

Candida albicans ATCC-90028, C. tropicalis LM-69, C. guilliermondii LM-28, C. krusei LM-07, C. stellatoidea LM-46 and C. parapsilosis CM-01 strains were used as test microorganisms. These strains were obtained from the microorganism collection of the Laboratory of Mycology, Health Science Center, Federal University of Paraíba (João Pessoa, Brazil). Stock cultures were kept on Sabouraud agar slants at $\pm 7^{\circ} \mathrm{C}$. Yeasts inocula, were prepared by inoculating a loopfull of overnight cultures (cultivated on Sabouraud agar slants at $\left.28{ }^{\circ} \mathrm{C}\right)$ in sterile saline solution $(\mathrm{NaCl} 0.85 \% \mathrm{w} / \mathrm{v})$ followed by shaking using vortex for 5 minutes. Yeast suspensions had their turbidity compared and adjusted to the McFarland 0.5 tube turbidity providing an inoculum of approximately $10^{6}$ colony forming unity per $\mathrm{mL}$.

\section{Antifungals}

Amphotericin B (100 $\mu \mathrm{g} / \mathrm{mL})$, ketoconazole (50 $\mu \mathrm{g} / \mathrm{mL})$ and itraconazole $(50 \mu \mathrm{g} / \mathrm{mL}$ ) were chosen for inclusion in the antimicrobial assays based on their availability in the Centers of Basic Assistance in Health of the Brazilian Health Public System. The sensitivity of the Candida strains to the tested antifungals were assessed by the solid medium procedure using paper discs (Sensibiodisc - Cecon, Saõ Paulo, Brazil) (Bauer et al., 1966).

\section{Determination of the essential oil Minimum Inhibitory Concentration - MIC}

Solid medium diffusion procedure using wells in dishes was used to determine the $P$. amboinicus essential oil MIC. For this, $1 \mathrm{~mL}$ of the yeast inoculum (approximately $10^{6} \mathrm{cfu} / \mathrm{mL}$ ) was uniformly spread on sterile Sabouraud agar Petri dishes. After inoculum absorption by Sabouraud agar, wells were made using sterile glass tubes (diameter $6 \mathrm{~mm}$ ) which were filled with $50 \mu \mathrm{L}$ of the essential oil solutions with different 
concentrations (Hadaceck; Greger, 2002; Souza et al., 2007). The system was incubated at $28^{\circ} \mathrm{C}$ for 48 hs. At the end of the incubation period, the MIC was the lowest essential oil concentration showing growth inhibition zones with diameters equal to or greater than $10 \mathrm{~mm}$. Controls included in this assay were essential oil replaced by sterile water.

\section{Interference of the essential oil on the antifungal anti- Candida activity}

Interference of $P$. amboinicus essential oil on the antifungal anti-Candida activity was assessed by the solid medium diffusion procedure using paper discs. Prior the anti-yeast assays, the antifungals paper discs were soaked with $20 \mu \mathrm{L}$ of the essential oil solution adjusted to have a concentration similar to the MIC value previously found. After that, $1 \mathrm{~mL}$ of the yeast suspension (approximately $10^{6} \mathrm{cfu} / \mathrm{mL}$ ) was uniformly spread on sterile agar Sabouraud Petri dishes. After inoculum absorption by Sabouraud agar, the paper discs (Whartman n. 1, diameter $6 \mathrm{~mm}$ ) were placed on the inoculated agar. The system was incubated at $28{ }^{\circ} \mathrm{C}$ for 48 hours. At the end of the incubation period, the interference of the essential oil on the antifungal anti-Candida activity was evaluated. Synergic effect was regarded when observed yeast growth inhibition zone resulting of the combined use of antifungal and essential oil, with diameter equal to or higher than $2 \mathrm{~mm}$ in comparison to the one found when the antifungal was assayed alone. Antagonic effect was regarded when observed yeast growth inhibition zone resulting of combined use of antifungal and essential oil, with diameter smaller than the one found when the antifungal was assayed alone. No interference was regarded when observed no change in the yeast growth inhibition zone diameter when the antifungal was assayed alone and combined with the essential oil (Cleeland; Squires, 1991; Oliveira et al., 2006). All assays were carried out in triplicate and the results were expressed as average of the three assays.

\section{RESULTS AND DISCUSSION}

Table 1 shows the sensitivity of Candida species to some clinically used antifungals. The assayed strains presented sensitivity behavior to the $P$. amboinicus essential oil however it was depending on the yeast strain and assayed antifungal. C. albicans was the only strain sensitive for all tested antifungals showing yeast growth inhibition zones with diameter between 10 and $16 \mathrm{~mm}$. On the other hand, C. krusei and C. stellatoidea presented resistance to all tested antifungals.

Table 2 shows the MIC values of $P$. amboinicus essential oil on Candida species. $P$. amboinicus essential oil presented MIC value of $40 \mu \mathrm{L} / \mathrm{mL}$ for the most assayed strains providing growth inhibition zones with diameter between 10 and $12 \mathrm{~mm}$. Essential oil highest MIC value
(80 $\mu \mathrm{L} / \mathrm{mL})$ was found to $C$. tropicalis.

C. stellatoidea was the only strain that showed resistance to the essential oil at all assayed concentrations. Antimicrobial properties in $P$. amboinicus essential oil on bacteria and/or fungal strains were found for some researchers, although its antimicrobial effectiveness has varied according to the target microorganisms, microbial inoculum, method and essential oil assayed concentrations (Aguiar, 2004; Oliveira et al., 2006).

Thymol and carvacrol, both phenolic compounds, have been reported as the majority compounds of $P$. amboinicus essential oil and are considered to be responsible for its antimicrobial property (Alves, 2000). Carvacrol and thymol present capability of dissolving into the cytoplasm membrane aligning among the fatty acid chains providing an increase in the cytoplasm membrane passive permeability (Lambert et al., 2001; Souza et al., 2007).

Table 3 shows the interference of $P$. amboinicus essential oil on the anti-Candida activity of some clinically used antifungals. The essential oil was assayed at concentration of $40 \mu \mathrm{L} / \mathrm{mL}$ because it was the MIC value found to the most Candida strains (Table 2). $P$. amboinicus essential oil showed some interference on the anti-Candida activity of the assayed antifungals noted by the formation of yeast growth inhibition zones with different diameters when the antifungal was assayed alone (Table 1) and combined with the essential oil (Table 3). Amphotericin B showed the smallest interference of the essential oil.

P. amboinicus essential oil presented a high interference on the anti-Candida property of itraconazole providing an enhancing (synergic effect) of its inhibitory effect on C. albicans, C. tropicalis, C. krusei and $C$. stellatoidea. On the other hand, it was observed an antagonic effect of the essential oil on the anti-C. krusei activity of itraconazole. Ketoconazole presented an interference of the essential oil in the interactions with C. albicans, C. guilliermondii and C. stellatoidea being found, respectively, an antagonic and synergic effect. Moreover, C. stellatoidea presented resistance to $P$. amboinicus essential oil (Table 1) and all tested antifungals (Table 2), however when the antifungals were assayed combined with the essential oil it was noted a change in its behavior (resistance to sensitivity) to ketoconazole and itraconazole.

Researchers emphasizing the interactions of industrialized drugs with medicinal plants are still little explored. Figueiredo et al. (2000) studying the associate use of medicinal plants used in the folk medicine of different Brazilian regions reported a lack of scientific data on the possible pharmacological interactions when different medicinal plants are used concomitantly to industrialized drugs. Some researches have noted some interference of medicinal plants and/or derivatives on the pharmacological effects of antimicrobial, antihypertensive, anti-coagulating and hypo-glycemic drugs 
Table 1. Sensitivity of Candida species to some clinically used antifungals ${ }^{\text {a }}$

\begin{tabular}{l|c|c|c|c}
\hline \multirow{2}{*}{\multicolumn{1}{c|}{ Yeasts }} & \multicolumn{4}{c}{ Antifungicals } \\
\cline { 2 - 5 } & amphotricin B & ketoconazole & itraconazole & strain viability \\
\hline C. albicans & 10 & 16 & 12 & + \\
C. tropicalis & 10 & 0 & 0 & + \\
C. guilliermondii & 0 & 15 & 11 & + \\
C. krusei & 0 & 0 & 0 & + \\
C. stellatoidea & 0 & 0 & 0 & + \\
C. parapsilosis & 0 & 18 & 12 & + \\
\hline
\end{tabular}

+: yeast growth in Sabouraud agar without adding essential oil or synthetic antifungal

a results expressed in yeast growth inhibition zones diameters $(\mathrm{mm})$

Table 2. MIC of P. amboinicus essential oil on Candida species.

\begin{tabular}{l|c|c}
\hline \multicolumn{1}{c|}{ Yeasts } & MIC $(\mu \mathrm{L} / \mathrm{mL})$ & $\begin{array}{c}\text { Yeast inhibition zone diameter } \\
(\mathrm{mm})\end{array}$ \\
\hline C. albicans & & 11 \\
C. tropicalis & 40 & 10 \\
C. guilliermondii & 80 & 12 \\
C. krusei & 40 & 10 \\
C. stellatoidea & 40 & 0 \\
C. parapsilosis & $\mathrm{R}$ & 10 \\
\hline
\end{tabular}

R: resistant for all assayed concentrations

Table 3. Interference of $P$. amboinicus essential oil on the anti-Candida activity of some clinically used antifungals ${ }^{\mathrm{a}, \mathrm{b}}$.

\begin{tabular}{l|c|c|c}
\hline \multirow{1}{*}{\multicolumn{1}{c|}{ Yeasts }} & \multicolumn{2}{c}{ Association } \\
\cline { 2 - 4 } & $\begin{array}{c}\text { amphotericin B } \\
+ \text { essential oil }\end{array}$ & $\begin{array}{c}\text { ketoconazole } \\
+ \text { essential oil }\end{array}$ & $\begin{array}{c}\text { itraconazole } \\
+ \text { essential oil }\end{array}$ \\
\hline C. albicans & $10 *$ & $12 \downarrow$ & $15 \uparrow$ \\
C. tropicalis & $10^{*}$ & $0 *$ & $12 \uparrow$ \\
C. guilliermondii & $0 *$ & $20 \uparrow$ & $8 \downarrow$ \\
C. krusei & $13 \uparrow$ & $0 *$ & $10 \uparrow$ \\
C. stellatoidea & $0 *$ & $15 \uparrow$ & $14 \uparrow$ \\
C. parapsilosis & $0 *$ & $18 *$ & $13 *$ \\
\hline
\end{tabular}

${ }^{a}$ results expressed in yeast growth inhibition zones diameters $(\mathrm{mm})$

${ }^{\mathrm{b}} P$. amboinicus essential oil assayed at concentration of $40 \mu \mathrm{L} / \mathrm{mL}$

+ : yeast growth in Sabouraud agar without adding essential oil or synthetic antifungal

* no interference

$\uparrow$ : synergic effect

$\downarrow$ : antagonic effect

(Alonso, 1998; Nascimento et al., 2005; Veiga Júnior et al., 2005).

Regarding our results $P$. amboinicus essential oil presents capability of interfering on the anti-Candida effectiveness of some clinically used antifungals, mainly itraconazole and ketoconazole. However, this interference depended on the Candida strain and assayed antifungal. Concomitant use of medicinal plants and/or derivatives with industrialized drugs is still a wide research field to be explored in order to discover the occurrence and ways by which plant products can interfere on the treatment of many diseases, particularly, microbial diseases.

\section{REFERENCES}

Aguiar FB 2004. Ensaios clínicos de fase II para avaliação de um fitoterápico composto (Schinus terebinthifolius Raddi, Plectranthus amboinicus Lour e Eucalyptus globulus Labill). João Pessoa, 138p. Tese de Doutorado - Programa de Pós-graduação em produtos naturais e sintéticos bioativos. Universidade Federal da Paraíba.

Alonso JR 1998. Tratado de fitomedicina: bases clinicas y farmacologicas. ISIS Ediciones, Buenos Aires.

Alves TMA 2000. Biological screening of Brazilian medicinal plants. Mem I Oswaldo Cruz 95: 367-373. 
Bauer AW, Kirby WM, Sherris SC, Turck M 1966. Antibiotic susceptibility testing by a standardized single disc method. Am J Clin Pathol 45: 493-496.

Brinker FND 1998. Herb contra-indications and drug interactions. Eclectic Medical Publications, Oregon.

Burt S 2004. Essential oils: their antibacterial properties and potential applications in foods - a review. Int J Food Microbiol 942: 223-253.

Calixto JB 2000. Efficacy, safety, quality, control, marketing and regulatory guidelines for herbal medicines (Phytotherapeutic agents). Braz J Med Biol Res 33: 179-189.

Castillo RAM, González VP 1999. Plectranthus amboinicus (Lour.) Spreng. Revista Cubana de Plantas Medicinales 33: 23-32.

Cleeland L, Squires E 1991. Evaluation of new antimicrobials in vitro and experimental animal infections. In: Lorian, V.M.D. (Ed.), Antibiotics in laboratory medicine. Willians \& Wilkins, pp. 739-788.

Dorigoni PA 2001. Levantamento de dados sobre plantas medicinais de uso popular no município de São João de Polêsine, RS, Brasil. I - Relação entre enfermidades e espécies utilizadas. Rev Bras Plant Med 4: 69-79.

Duarte MCT, Figueira GM, Sartoratto A, Rehder VLG, Delarmelina C 2005. Anti-Candida activity of Brazilian medicinal plants. J Ethnopharmacol 97: 305-311.

Figueiredo CAV 2000. As plantas medicinais e interações medicamentosas. In: Simpósio Nacional de Plantas Medicinais, Recife, Brazil, pp. 253.

Hadacek F, Greger H 2000. Testing of antifungal natural products: methodologies, comparability of results and assay choose. Phytochem Analysis 1: 137-147.

Lambert RJW, Skandamis PN, Coote P, Nychas GJE 2001. A study of the minimum inhibitory concentration and mode of action of oregano essential oil, thymol, and carvacrol. J Appl Microbiol 91: 453-462.

Lima IO, Oliveira RAG, Lima EO, Farias NMP, Souza EL 2006a. Atividade antifúngica de óleos essenciais sobre espécies de Candida. Rev Bras Farmacogn 16: 197-201.

Lima IO, Oliveira RAG, Lima EO, Farias NMP, Souza EL 2006b. Atividade antifúngica de óleos essenciais sobre espécies de Candida. Rev Bras Farmacogn 16: 197-201.

Lima MRF, Ximenes CPA, Luna JS, Sant'Ana AEG 2006c. The antibiotic activity of some Brazilian medicinal plants. Rev Bras Farmacogn 16: 300-306.

Lorenzi H, Matos FJA 2002. Plantas medicinais no Brasil: nativas e exóticas. Instituto Plantarum, Nova Odessa.

Morais SM, Dantas JDP, Silva ARA, Magalhães EF 2005. Plantas medicinais usadas pelos índios Tapebas do Ceará. Rev Bras Farmacogn 15: 169-177.

Nascimento GF 2005. Antibacterial activity of plant extracts and phytochemicals on antibiotic-resistant bacteria. Braz J Microbiol 31: 251-257.

Oliveira RAG, Lima EO, Vieira WL, Freire KRL, Trajano
VN, Lima IO, Souza EL, Toledo MS, Silva Filho RN 2006. Estudo da interferência de óleos essenciais sobre alguns antibióticos usados na clínica. Rev Bras Farmacogn 16: 77-82.

Packer JF, Luz MMS 2007. Método para avaliação e pesquisa da atividade antimicrobiana de produtos de origem natural. Rev Bras Farmacogn 17: 102-107.

Radhrakrishanan-Sridhar S, Velusamy-Rajagopal R, RamasamyRajavel R 2003. Antifungal activity of some essential oils. J Agric Food Chem 51: 7596-7599.

Schwartz R 2004. Superficial fungal infections. Lancet 364: 1173-1182.

Seidil PR 2000. Pharmaceuticals from natural products. An Acad Bras Cienc 74: 145-150.

Sellar W 2002. Óleos que curam. O poder da aromaterapia. Nova Era, Rio de Janeiro. 230p.

Souza EL, Lima EO, Freire KRL, Sousa CP 2005. Inhibitory action of some essential oils and phytochemicals on the growth of moulds isolated from foods. Braz Arch Biol Technol 2: 245-250.

Souza EL, Stamford TLM, Lima EO, Trajano VN 2007. Effectiveness of Origanum vulgare L. essential oil to inhibit the growth of food spoiling yeasts. Food Control 18: 409-413.

Sucar DD 2003. Fundamentos de interações medicamentosas dos psicofármacos como outros medicamentos da clínica médica. Lemos Editorial, São Paulo.

Tôrres AR, Oliveira RAG, Diniz MFFM, Araújo EC 2005. Estudo sobre o uso de plantas medicinais em crianças hospitalizadas da cidade de João Pessoa: riscos e benefícios. Rev Bras Farmacogn 15: 373-380.

Veiga Júnior VF, Pinto AC, Maciel MAM 2005. Plantas medicinais: cura segura? Quim Nova 28: 519-528.

Wilhelmus KR 2005. Climatology of dematiaceous fungal keratitis. Am J Ophtalm 140: 156-1157. 